Atmos. Chem. Phys. Discuss., 11, 14719-14746, 2011

www.atmos-chem-phys-discuss.net/11/14719/2011/

doi:10.5194/acpd-11-14719-2011

(C) Author(s) 2011. CC Attribution 3.0 License.
Atmospheric

Chemistry and Physics Discussions

\title{
Characterization of gas station emissions during the CAREBeijing 2008 field study
}

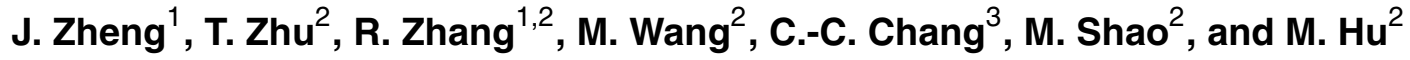

${ }^{1}$ Department of Atmospheric Sciences, Texas A\&M University, Texas 77843, USA

${ }^{2}$ State Key Laboratory of Environmental Simulation and Pollution Control, College of Environmental Sciences and Engineering, Peking University, Beijing, 100871, China

${ }^{3}$ Research Center for Environmental Changes, Academia Sinica, Taipei 11529, Taiwan

Received: 22 April 2011 - Accepted: 1 May 2011 - Published: 13 May 2011

Correspondence to: T. Zhu (tzhu@pku.edu.cn)

Published by Copernicus Publications on behalf of the European Geosciences Union.

Characterization of gas station emissions

J. Zheng et al.

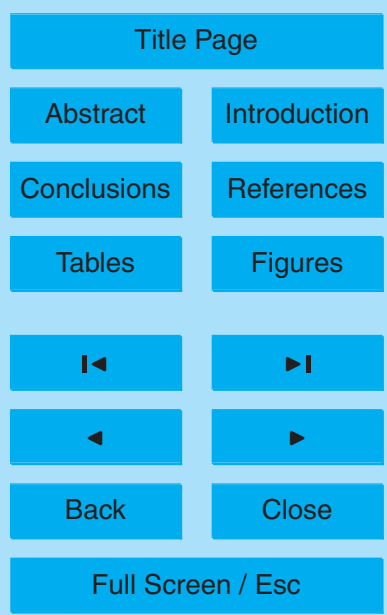

Printer-friendly Version

Interactive Discussion 


\section{Abstract}

A proton transfer-reaction mass spectrometer (PTR-MS) onboard a mobile laboratory was used to conduct emission measurements at eight gas stations in Beijing during the CAREBeijing 2008 campaign. Benzene, toluene, $\mathrm{C}_{8^{-}}, \mathrm{C}_{9}$-aromatics, methanol,

5 MTBE, butenes and pentenes were the major volatile organic compounds (VOCs) detected during the measurements. An inter-comparison between the PTR-MS and an on-line GC/MS/FID system was also conducted and the result showed good agreement between the two instruments (Interception $<0.08$ ppbv, $0.72<$ Slope $<0.95$, and $R^{2}>0.92$ ). A Gaussian point source plume model was applied to evaluate the VOCs 10 emission rates. The results showed that on average about $4.5 \mathrm{mt}$ of gasoline were emitted from gas stations in Beijing per day. The estimated emission factor (EF) for gas stations due to refueling processes was about $0.5 \mathrm{~kg} \mathrm{t}^{-1}$, which was significantly lower than a value of $2.49 \mathrm{~kg} \mathrm{t}^{-1}$ obtained in 2002, indicating a successful implementation of vapor recovery system in the gas stations of Beijing. On average, about $18 \mathrm{ppbv}$ 15 of benzene has been detected at one gas station, twice as much as the US Environmental Protection Agency (EPA) recommended safe chronic exposure level and implying a potential public health concern. MTBE and aromatics were found to be the major antiknocking additives used in gasoline supplied in Beijing. Our results reveal that emissions from gas stations represent an important source for VOCs in megacity Beijing and need to be properly included in emission inventories to assess their roles in photochemical ozone production and secondary organic aerosol formation. Furthermore, promoting methanol-blended fuel in Beijing can be an effective way to reduce toxic air pollutants emission.

\section{Introduction}

25 Rapid urbanization in the Beijing area leads to a fast growth in automobile population. At an annual rate of $14.5 \%$ (Hao et al., 2006), it is projected that the number of vehicles

Characterization of gas station emissions

J. Zheng et al.

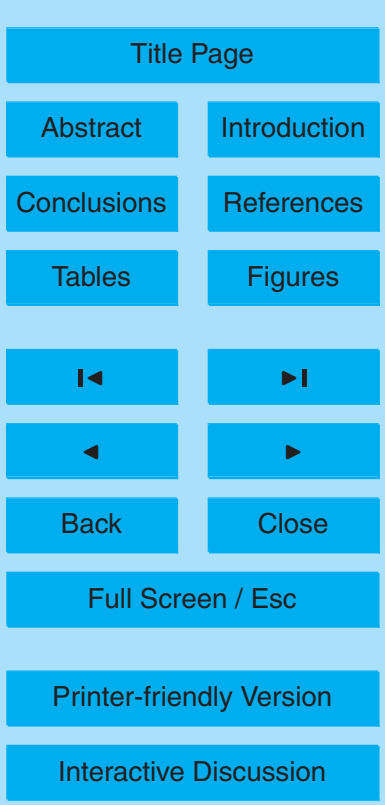

Interactive Discussion 
in Beijing will reach five million (Han and Hayashi, 2008) by 2020. Automobile-related air pollutants emissions account for more than $70 \%$ of volatile organic compounds (VOCs) and $40 \%$ of nitrogen oxides $\left(\mathrm{NO}_{\mathrm{x}}\right)$ emissions in the Beijing metropolitan area (Liu et al., 2005; Hao et al., 2006), which trigger rapid ozone photochemical production

5 (Finlayson-Pitts and Pitts, 1999; Zhang et al., 2004a) and lead to secondary organic aerosol formation (Zhao et al., 2009; Yue et al., 2010; Zhang, 2010). Consequently, severe air pollution episodes characterized by high $\mathrm{O}_{3}$ concentration and particulate matter are often encountered in Beijing summertime (Tang, 2004), with the potential to impact regional and global climate (Zhang et al., 2007).

10 Gasoline emission due to fuel handing and storage at gas stations represents a major component of the VOC inventory in China. It was estimated that near $187.6 \mathrm{kt}$ of VOCs were emitted into the atmosphere from gas stations allover China in 2002 (Shen et al., 2006). As the host of the 2008 Summer Olympic Games and due to international concerns on athletes' health during competition, the Beijing municipal administration 15 pledged to improve Beijing's air quality and present a "Green Olympic Games". Since 2002, a series of emission control measures have been implemented in the Beijing City area, especially targeting at VOCs. By May 2008, the Beijing Environmental Protection Bureau (BEPB) has shut down 144 gas stations and storage facilities for failure to comply with the vapor recovery rule that requires all the gas pumps install specially designed nozzle to collect vapors from the vehicle's gas tank and return these collected vapors to the service station's underground storage tank.

Despite different refinery techniques and crude oil origins, typical gasoline mainly consists of $\mathrm{C}_{4}-\mathrm{C}_{12}$ hydrocarbons (i.e., paraffins, naphthenes, and olefins) and substantial amount of antiknocking additives, which prevent gasoline from autoignition under 25 a high compression ratio to improve engine performance and achieve a higher fuel efficiency. Gasoline is typically classified by an octane number, a measure of resistance of gasoline to autoignition with references to iso-octane as No. 100 and $n$-heptane as No. 0. In this work, we consider the research octane numbers, i.e., RON. Currently, aromatics (i.e., benzene, toluene, xylenes, and ethylbenzene) and oxygenate

Characterization of gas station emissions

J. Zheng et al.

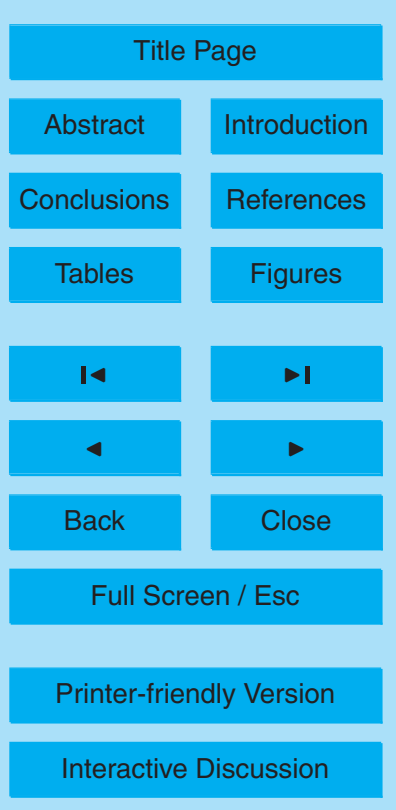

Interactive Discussion 
compounds, such as methyl tertiary butyl ether (MTBE), methanol and ethanol, are the most widely used antiknocking additives. Most of the aromatics have adverse effects on human health after either chronic or acute exposure. Particularly, benzene is classified as a carcinogen by the world health organization $(\mathrm{WHO})$ and is primary released 5 into the atmosphere through fugitive emission due to its use in gasoline and industrial solvent. Moreover, aromatics are also considered as highly reactive VOCs (Suh et al., 2002, 2003; Atkinson and Arey, 2003; Zhao et al., 2005) and oxidation of aromatic hydrocarbons plays an important role in the nucleation and growth of secondary organic aerosols (Zhang et al., 2004b; Zhao et al., 2006; Wang et al., 2010). Thus, fugitive 10 gasoline emission from gas stations can contribute significantly to $\mathrm{O}_{3}$ production potential. Oxygenate additives can add "oxygen" into the fuel and help gasoline burn more completely, reducing toxic exhaust emissions. For example, methanol has been suggested to be a promising alternative fuel for gasoline (Reed and Lerner, 1973). Since methanol has only one carbon atom, it can burn much cleanly and exhaust nearly only carbon dioxide and water. Methanol blended gasoline can significantly reduce carbon monoxide (CO), $\mathrm{NO}_{\mathrm{x}}$, and aldehyde emissions. Despite the environmental benefits, oxygenate gasoline additives also cause health concerns. For instance, inhalation of MTBE vapor can cause damage to human organs and it is also considered as a possible carcinogen (US EPA report 600/R-94/217). Because methanol is practically odorless and has a high toxicity in human, people may be unaware of exposure to high level of methanol vapor and suffer metabolic acidosis and ocular toxicity (Tephly, 1991). Hence, speciation and quantification of VOCs in the gasoline plume from gas stations are of importance to establish accurate VOC emission inventories, to assess its impact on $\mathrm{O}_{3}$ production potential, and to evaluate its effects on public health, especially for residents in the immediate vicinity of the gas stations.

As part of the 2008 Campaign of Air Quality Research in Beijing and Surrounding Regions (CAREBeijing 2008), measurements of VOC plumes originating from eight gas stations were conducted using a PTR-MS onboard a mobile laboratory to characterize emissions from gas stations. The performance of the PTR-MS has been validated by

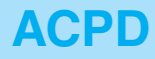

$11,14719-14746,2011$

Characterization of gas station emissions

J. Zheng et al.

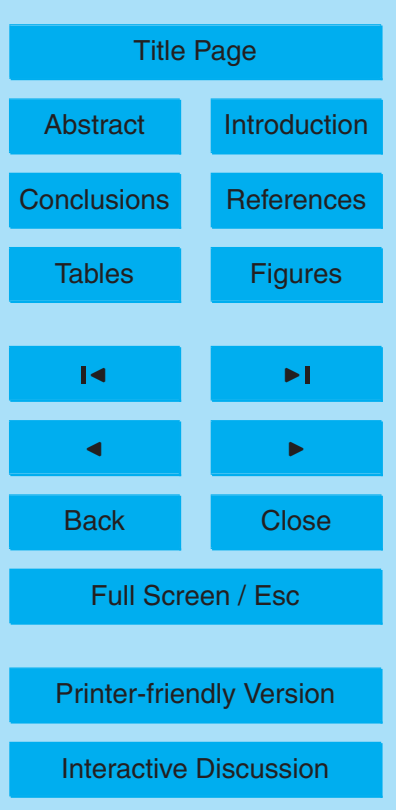


inter-comparison with an on-line GC system. The advantage of this work lies in the combination of the mobility of the mobile laboratory and the high sensitivity and fast time-response instrumentation. Aromatics and oxygenated additives in these gasoline plumes are the focus, because of their significant contribution to photochemical $\mathrm{O}_{3}$ 5 production, secondary organic aerosol formation, and public health concerns.

\section{Experimental}

\subsection{Mobile Laboratory and PTR-MS}

The PTR-MS was onboard a mobile laboratory $(\mathrm{ML})$, which was modified from an IVECO Turin $\mathrm{V}$ diesel vehicle. A detailed description of the $\mathrm{ML}$ and the onboard in10 strumentation has been provided by Wang et al. (2009). Only information relevant to the present work is briefly introduced here. The ML was $6.6 \mathrm{~m}$ long, $2.4 \mathrm{~m}$ wide, and $2.8 \mathrm{~m}$ high, with a total payload of about 2.7 metric ton. Besides PTR-MS, the ML was equipped with a suite of research grade commercial instruments for both aerosol and gaseous species measurements. The $\mathrm{NO}_{x}$ data used in this work was measured by an ECOTECH $9841 \mathrm{~A}$ chemiluminescence $\mathrm{NO}_{\mathrm{x}}$ analyzer with a $0.4 \mathrm{ppbv}$ detection limit at $1 \mathrm{~s}$ response time. To prevent self-contamination, the ML was powered by two sets of $12 \mathrm{~V} / 110$ Ah lead rechargeable batteries during on-road measurements, which lasted up to about four hours. All sampling inlets were mounted on the front top of the $\mathrm{ML}$, about $3.2 \mathrm{~m}$ above the ground. The VOC inlet was made of a $1.5 \mathrm{~m}$ long $1.6 \mathrm{~mm}$ ID PFA tubing and the sampling rate was about 350 standard cubic centimeters per minute $(\mathrm{sccm})$ to achieve a residence time less than $1 \mathrm{~s}$.

The PTR-MS (Hansel et al., 1995) was a commercial instrument manufactured by Ionicon Analytik. In operation, water molecules were first ionized by a hollow cathode discharge ion source into hydronium ions $\left(\mathrm{H}_{3} \mathrm{O}^{+}\right)$, which then reacted with VOC molecules through proton-transfer reactions inside a drift-tube under a well-defined electric field. The protonated VOC species $\left(\mathrm{R}^{+}\right)$were further analyzed by a quadrupole

\section{ACPD}

$11,14719-14746,2011$

Characterization of gas station emissions

J. Zheng et al.

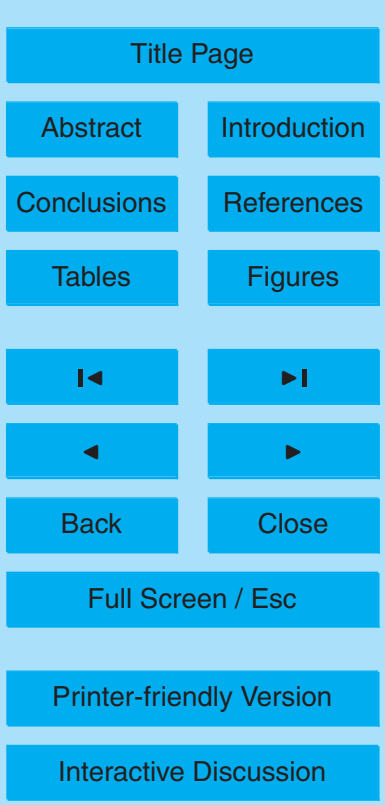


mass spectrometer. The detailed PTR-MS operating conditions have been introduced by Fortner et al. (2009). Quantification of the VOC analytes was based on kineticlimited calculations (Lindinger et al., 1998; Zhao and Zhang, 2004) and calibrations with commercial standard mixtures (Spectra Gases Inc.) from the USEPA TO-15 tar5 get compounds list. A custom made catalytic converter (Fortner et al., 2009) was used for both background checks and calibration, which was typically before or after each measurement trip.

In this work, pentenes, benzene, toluene, $\mathrm{C}_{8}$-aromatics, $\mathrm{C}_{9}$-aromatics, and methanol were identified and quantified at $m / e 71,79,93,107,121$, and 33 , respectively (de 10 Gouw and Warneke, 2007). Although the molecular weight of MTBE is 88, it exclusively fragments into $\mathrm{m} / \mathrm{e} 57$ after protonation, as confirmed by calibrations with commercial MTBE standards (Apel-Riemer Environmental Inc.). In addition, butenes were also detected at $m / e 57$ with a similar calibration factor. Based on the analysis of canister samples taken in Beijing during August 2005, Song et al. (2008) identified the gasoline emission profile, which contained about $4.1 \%$ butenes and $4.7 \%$ MTBE by volume. Accordingly, we attributed $47 \%$ of the $\mathrm{m} / \mathrm{e} 57$ signal intensity to butenes and the other $53 \%$ to MTBE. The detection limit (defined as $3 \sigma$ of the background noise) of each VOC was less than $0.5 \mathrm{ppbv}$ except for methanol, with a value of $2 \mathrm{ppbv}$ due to its higher background level. Although gasoline contained significant portion of other hydrocarbons, most of them were alkane species and can not be detected by PTR-MS effectively (Arnold et al., 1998).

\subsection{GC/MS/FID VOC measurement}

An on-line automated gas chromatography system with mass spectrometry and flame ionization dual-detectors (GC/MS/FID, Varian CP-3800 and Saturn 2200 MS) was de25 ployed to measure $\mathrm{C}_{1}-\mathrm{C}_{11}$ VOCs on the campus of Peking University during the campaign. The inlet of the system was set up on the roof of a six-story building $(\sim 25 \mathrm{~m}$ above ground). The on-line GC/MS system used here is a modification described by Chang et al. (2010). A built-in cryo-trap packed with fine glass beads was cooled with
$11,14719-14746,2011$

Characterization of gas station emissions

J. Zheng et al.

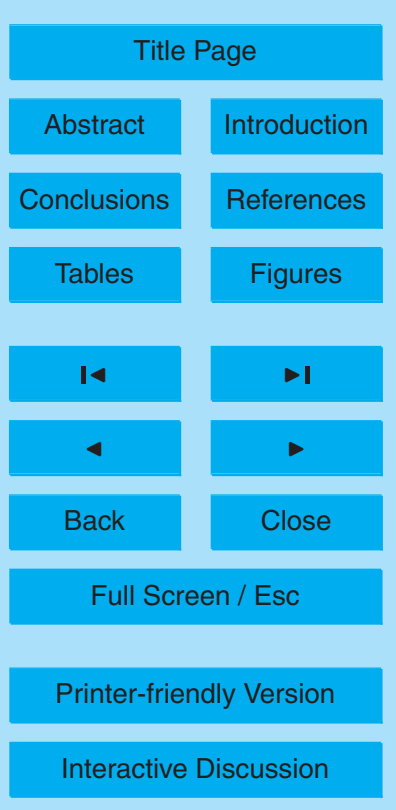

Interactive Discussion 
liquid nitrogen to $-170^{\circ} \mathrm{C}$ for trapping. Air sample was drawn from the sample inlet through the cryo-trap at a rate of $12 \mathrm{ml} \mathrm{min}^{-1}$ for $20 \mathrm{~min}$, which provided an aliquot of $240 \mathrm{ml}$ air sample for each analysis. Desorption was made by flash heating of the trap to $85^{\circ} \mathrm{C}$, and a stream of ultra-high purity helium (99.9999\%) was used to flush the 5 trapped hydrocarbons onto the columns. A glass Y-splitter separated the flow to two columns, i.e., a PLOT column (Chrompack; $30 \mathrm{~m} \times 0.32 \mathrm{~mm}$; $\mathrm{df}=5.0 \mu \mathrm{m}$ ) connected to FID for separation and detection of $\mathrm{C}_{2}-\mathrm{C}_{4}$ hydrocarbons, and a DB-1 column (J\&W; $60 \mathrm{~m} \times 0.32 \mathrm{~mm}$; $\mathrm{df}=1.0 \mu \mathrm{m}$ ) connected to $\mathrm{MS}$ for the separation and detection of $\mathrm{C}_{5^{-}}$ $\mathrm{C}_{11}$ hydrocarbons, $\mathrm{C}_{1}-\mathrm{C}_{3}$ halogenated hydrocarbons, ethers, esters, and other VOCs. 10 The $\mathrm{GC}$ oven started at $-15^{\circ} \mathrm{C}$ for $1.5 \mathrm{~min}$, ramped to $0^{\circ} \mathrm{C}$ at $10^{\circ} \mathrm{C} \mathrm{min}^{-1}$, to $140^{\circ} \mathrm{C}$ at $5^{\circ} \mathrm{C} \mathrm{min}^{-1}$, to $180^{\circ} \mathrm{C}$ at $20^{\circ} \mathrm{C} \mathrm{min}^{-1}$, and ended at $180^{\circ} \mathrm{C}$ for $9.5 \mathrm{~min}$. The mass spectrometer detector was operated in the total ion current (TIC) mode, but only one or few ions (usually the primary ion or ions with less interference in chromatogram) for each target compound was used for quantitative analysis in order to reduce interference.

15 Four internal standards (bromochloromethane, 1,4-difluorobenzene, chlorobenzened5, and 1-bromo-4-fluorobenzene) were blended in for each injection aliquot to confirm the stability of MS and to ensure data quality. Precision for measured species was evaluated by repeated 7 analyses of a standard mixture at around 1 ppbv. The precisions (one standard deviation) and detection limits of the upgraded method for most species were $0.5-2 \%$ and 5-20 pptv, and the time resolution for the NMHC dataset was $1 \mathrm{~h}$.

\subsection{Gas station plume measurement}

Eight gas stations, located around the northwest corner of the 4th and 5th ring loops of the Beijing City (denoted as G1 to G8 in Fig. 2), were sampled by the ML on 6 and 10 August 2008. These gas stations were chosen since the traffic conditions 25 were fairly smooth and plumes due to traffic jam could be avoided. The measurement time was between 8 a.m. and 12 p.m., when morning rush hours had passed and gas stations were engaged in typical business activity. Neither strong precipitation nor high wind speed $\left(\sim 0.3\right.$ to $\left.0.6 \mathrm{~m} \mathrm{~s}^{-1}\right)$ were encountered during the measurements. Ambient

Characterization of gas station emissions

J. Zheng et al.

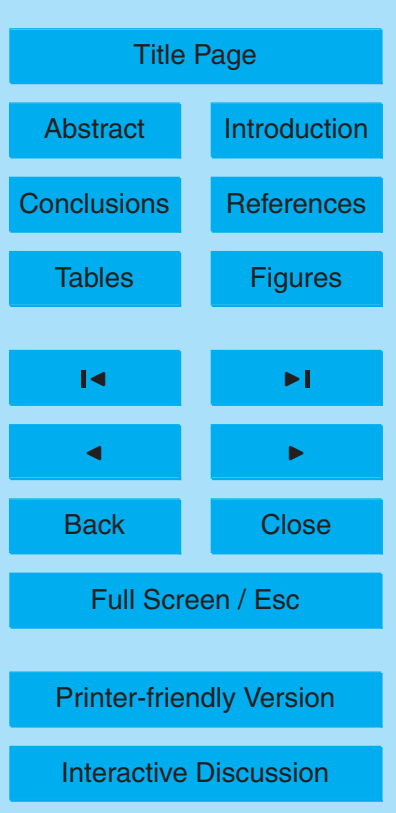


temperature and relative humidity $(\mathrm{RH})$ remained steady. The location, time of each measurement, and detailed meteorological conditions were summarized in Tables 1 and 2. Typically, the ML was selectively parked at the downwind side of the gas station, about $15 \mathrm{~m}$ from the fueling islands. Self-contamination was avoided by using the 5 rechargeable battery sets. The PTR-MS was set in selective ion monitor mode (SIM) and scanned methanol, MTBE, benzene, toluene, $\mathrm{C}_{8}$ - and $\mathrm{C}_{9^{-}}$aromatic compounds, and twenty masses for $1 \mathrm{~s}$ each consecutively thus to achieve a time resolution of $\sim 25 \mathrm{~s}$. Other trace gases, including $\mathrm{NO}_{\mathrm{x}}$ and meteorological parameters were also continuously monitored at $1 \mathrm{~Hz}$. The detailed operating procedure of the $\mathrm{ML}$ has been 10 provided by Wang et al. (2009).

\subsection{Gaussian plume model}

We considered a gas station as a point source emitter due to both refueling operations and evaporations from storage facility. As the plume travels downwind, it diffuses both vertically and horizontally and consequently its concentration is normally distributed in either direction. Therefore, a Gaussian plume model can be used to simulate the atmospheric diffusion process and to evaluate fugitive gasoline emission rate from the gas stations. Specifically, the model is based on the following assumptions: (1) the VOC concentrations in the plume are under steady state; (2) the mass within the plume is conserved; (3) wind and eddy diffusivities are constant as the plume traveled downwind. The Gaussian plume model is expressed as (Seinfeld and Pandis, 1998):

$C(x, y, z)=\frac{Q}{2 \pi u \sigma_{y} \sigma_{z}}\left\{\exp \left(\frac{-(z-h)^{2}}{2 \sigma_{z}^{2}}\right)+\exp \left(\frac{-(z+h)^{2}}{2 \sigma_{z}^{2}}\right)\right\}\left\{\exp \left(\frac{-(y)^{2}}{2 \sigma_{y}^{2}}\right)\right\}$

where $C$ is the concentration of the VOC species at the point of observation denoted by coordinates $(x, y, z), Q$ is the source emission rate in $\mathrm{gs}^{-1}, u$ is the wind speed in $\mathrm{ms}^{-1}$, and $h$ is the height of the point source (taken as $1 \mathrm{~m}$ here). $\sigma_{z}$ and $\sigma_{y}$ are

vertical and cross-wind plume distribution, respectively and are defined according to

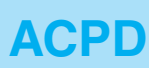

$11,14719-14746,2011$

Characterization of gas station emissions

J. Zheng et al.

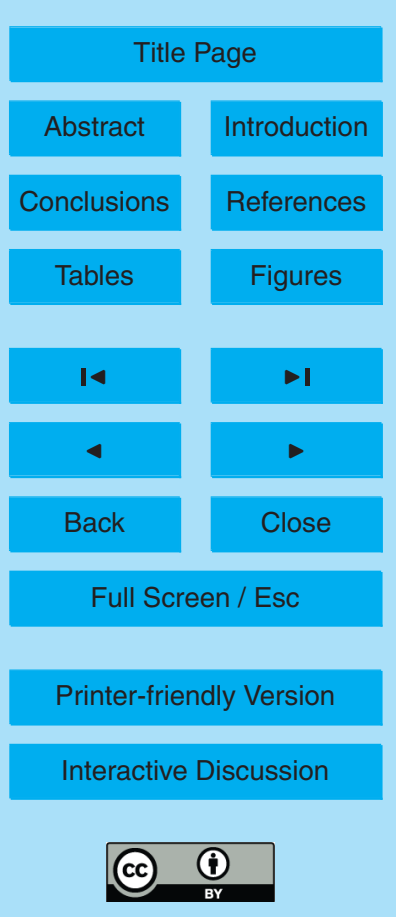


the Pasquill stability classifications (Gifford, 1976). In this work, considering the urban environment and the weather conditions (i.e., cloudy and low wind speed, less than $\left.1 \mathrm{~m} \mathrm{~s}^{-1}\right), \sigma_{z}$ and $\sigma_{y}$ are evaluated as $\sigma_{z}=0.24 x \cdot(1.0+0.001 x)^{0.5}$ and $\sigma_{y}=0.32 x \cdot(1.0+$ $0.0004 x)^{-0.5}$, respectively. Since the ML is directly parked downwind side of the gas 5 stations, its location is virtually estimated as ( $x \approx 15$ to $20 \mathrm{~m}, y \approx 0 \mathrm{~m}, z \approx 3.0 \mathrm{~m})$. Hence, from measured VOC concentrations $(C(x, y, z))$, the emission rates $(Q)$ of each VOC species can be calculated accordingly.

The accuracy of the Gaussian model was determined by the precision of all the parameters used in the calculation, among which the precise location of the ML relative to the fueling stations corresponded to the largest uncertainty. Both $x$ and $y$ were estimated with an uncertainty of $\pm 1 \mathrm{~m}$, leading to $-26 \%$ to $28 \%$ uncertainty in the results. The uncertainty of the PTR-MS measurements were less than $20 \%$ determined as two standard deviations of all calibrations conducted during the CAREBeijing campaign (Wang et al., 2009).

\section{Results and discussion}

\subsection{Inter-comparison between PTR-MS and GC/MS/FID}

Inter-comparisons between PTR-MS and other well-developed methods, such as GC based technique, have been routinely conducted during field measurements to evaluate the performance of both instrumentations (de Gouw et al., 2003; Kuster et al., 2004; Fortner et al., 2009). During the CAREBeijing 2008 campaign, an on-line automated GC/MS/FID system was also used to measure VOCs at the Peking University (PKU) site. From 24 to 25 August, the ML was parked immediately next to a six-story building, on the roof-top of which was the observatory that housed the GC/MS/FID at the PKU site. The vertical distance between the two instruments was about $30 \mathrm{~m}$. Because automobile traffic was limited on the campus, a local highway to the north of the site (about $200 \mathrm{~m}$ away) was the dominant source of traffic emission. Pine trees

Characterization of gas station emissions

J. Zheng et al.

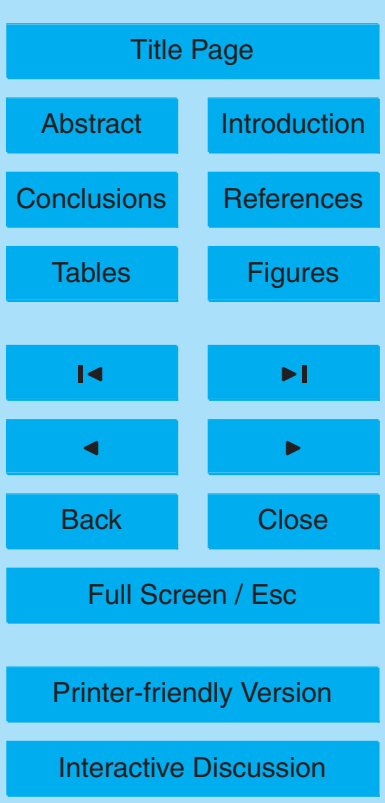


and shrubs were present along the building sidewall. Both instrument inlets were at least $10 \mathrm{~m}$ away from the tree crowns. Figure 1 shows the plots of isoprene, benzene, and toluene observed on 24 August by both the PTR-MS and the GC/MS/FID. The PTR-MS data is $10 \mathrm{~min}$ averaged to match the lower sampling frequency, $\sim 1 \mathrm{~h}$,

5 of the GC/MS/FID system. Overall, the agreement between the two systems is excellent. The slopes, interceptions and correlation coefficients $\left(R^{2}\right)$ of least square fits are $0.88,0.08 \mathrm{ppbv}$ and 0.92 for isoprene, $0.95,-0.06 \mathrm{ppbv}$ and 0.98 for benzene, and $0.72,0.06 \mathrm{ppbv}$ and 0.97 for toluene, respectively. Since isoprene is produced during photosynthesis and is predominantly lost due to reactions with hydroxyl radical (Zhang 10 et al., 2000, 2002), isoprene shows a typical diurnal pattern that highly correlates with the solar radiation, as shown in Fig. 1a. No clear diurnal patterns are present in both benzene and toluene time series, although a good correlation between them is found $\left(R^{2}=0.84\right)$ with a toluene/benzene (T/B) ratio of 1.78 determined by orthogonal distance regression (ODR), indicating a common source of fresh traffic emission (McKeen 15 and Liu, 1993).

\subsection{Gasoline emissions from gas stations}

Tables 1 and 2 summarize gas station measurements on 6 and 10 August 2008, containing the location, time, local meteorological conditions, and number of gasoline plumes intercepted at each site. Figures 3 and 4 display the time series of butenes, 20 pentenes, methanol, MTBE, benzene, toluene, $\mathrm{C}_{8}$ - and $\mathrm{C}_{9}$-aromatics measured on 6 and 10 August, respectively. Also shown in the figures is concurrently measured $\mathrm{NO}_{\mathrm{x}}$, which is only present in automobile exhaust and is used to distinguish the fugitive gasoline plumes from automobile emissions. Evidently, on-road $\mathrm{NO}_{\mathrm{x}}$ plumes of more than 200 ppbv are frequently observed between gas station stops, but no significant aromatics, MTBE, and methanol are simultaneously found within the $\mathrm{NO}_{\mathrm{x}}$ plumes. Occasionally, spikes of $\mathrm{NO}_{x}$ from refueling vehicles are also captured. However, these exhaust plumes typically appear slightly earlier than the gasoline plumes and are excluded from emission rate calculation.

Characterization of gas station emissions

J. Zheng et al.

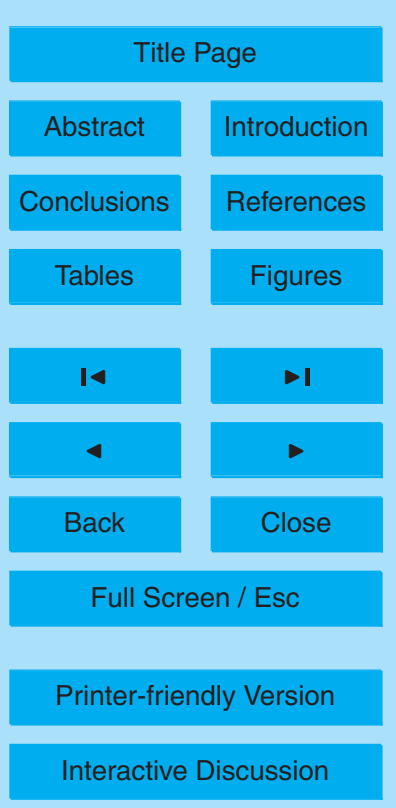


Figure 5 displays the box plots of the emission rates of VOCs in the plumes detected at the eight gas stations and Fig. 6 presents the corresponding bar plots of averaged VOC emissions at each gas station. Since alkanes cannot be detected by the PTR-MS, only eight VOC species are reported here, which account for about $34 \%$ of the total 5 gasoline emission (Song et al., 2008). It is shown that gasoline emissions from the gas stations vary significantly in terms of the emission rate and chemical composition. The observed highest and lowest emission rates are found at G3 and G6, respectively, with the values of $1.1 \times 10^{-1}$ and $1.4 \times 10^{-3} \mathrm{~g} \mathrm{~s}^{-1}$. From our observations at all the gas stations, one refueling process typically takes about $77 \mathrm{~s}$ and 16 vehicles are refueled per 10 hour. Assuming all 1442 gas stations in Beijing (BEPB) are operated $24 \mathrm{~h}$ a day with the averaged work load, we estimate that about $4.5 \mathrm{mt}$ of gasoline are emitted from gas stations per day or $1.6 \mathrm{kt} \mathrm{yr}^{-1}$. Since about $3409 \mathrm{kt}$ of gasoline have been consumed in Beijing during 2008 (National Bureau of Statistics of China, 2010), the VOC EF for gas stations in Beijing is evaluated as about $0.5 \mathrm{~kg} \mathrm{t}^{-1}$, i.e., $0.5 \mathrm{~kg}$ of every ton of gaso15 line supplied in Beijing are emitted into the atmosphere., Shen et al. (2006) reported a gasoline EF of $2.49 \mathrm{~kg} \mathrm{t}^{-1}$ before the vapor recovery systems were mandatorily installed in all gas stations of Beijing. Hence, our measurements indicate that gasoline emission due to refueling process was significantly reduced during the Olympics period.

The aromatics and oxygenated hydrocarbons can significantly increase gasoline octane rating. The RON rating of MTBE, methanol, benzene, toluene, $\mathrm{C}_{8}$ - and $\mathrm{C}_{9}$ aromatics (both are treated as xylene) are 116, 133,101,111,117, and 117, respectively. In this work, the mass-weighted octane rating of the six detected VOCs is about 114 , indicating that they are the major anti-knocking additives. In all cases a substantial amount of MTBE is found, accounting for $19 \%$ to $36 \%$ of the detected VOCs. Although MTBE does not participate in ozone production, its health risks are actively under debate. Currently, MTBE is not classified as a human carcinogen, but it has been suggested that MTBE can be a potential human carcinogen after high dose exposure, especially due to contamination of ground water by leakage from under-ground

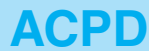

$11,14719-14746,2011$

Characterization of gas station emissions

J. Zheng et al.

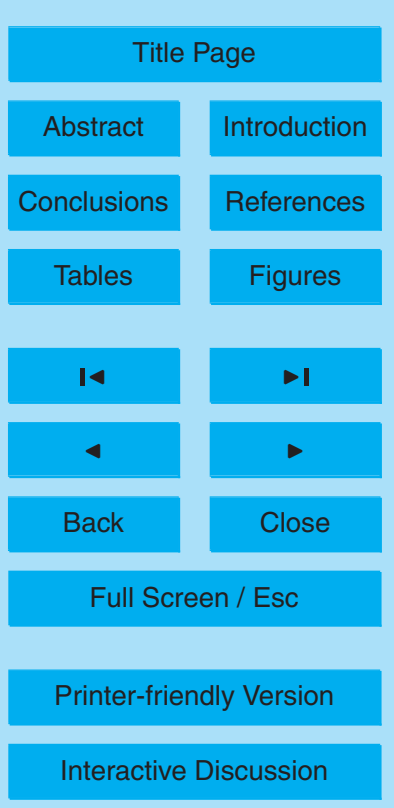


gasoline storage (US EPA, 2011).

Because benzene is a known carcinogen, its content in gasoline is regulated below $2.5 \%$ by volume in China (GB17930-2006). At five gas stations, benzene is found to be more than $4.1 \%$ of the detected VOCs, i.e., about $3 \%$ of the total gasoline vapors, 5 indicating that most gasoline supplied in China contains elevated benzene. Particularly, at G3, a maximum value of $164 \mathrm{ppbv}$ or an average value of $18 \mathrm{ppbv}$ for benzene is observed. In comparison, an average gasoline benzene content is about $1 \%$ by volume in the US and the US EPA's inhalation reference concentration (RfC, i.e., an estimate of a continuous inhalation exposure concentration to people that is likely to be without 10 risk of deleterious effects during a lifetime) for benzene is $3 \times 10^{-5} \mathrm{~g} \mathrm{~m}^{-3}$ or $\sim 9 \mathrm{ppbv}$ under standard atmospheric conditions. Averaged benzene concentrations at most of the gas stations appear to cause no serious health concern, except that at G3 benzene concentration is twice as much as the $\mathrm{RfC}$ value.

In general, all aforementioned VOCs are detected in all gasoline vapor plumes with 15 noticeable concentrations, except that a substantial amount of methanol is exclusively found in gasoline sold at G3 and G5. However, ethanol, a common additive used in the US, is not present in any brands of gasoline in Beijing and not detected by on-road PTR-MS measurements. Like other oxygenate gasoline additives, methanol has high octane number rating $(\mathrm{RON}=133)$ and combusts at a lower temperature than gasoline, and addition of methanol into traditional gasoline can significantly lower exhaust emission. It is found that $76 \%$ of antiknocking additives in gasoline sold at G3 and G5 are oxygenated in nature, while only $35 \%$ of antiknocking additives are oxygenated in the other cases. Currently, the supplier of G3 and G5 is operating 10 gas stations in the Beijing region, accounting for less than $1 \%$ of the Beijing region gasoline market.

25 Potentially, promoting methanol-containing gasoline in Beijing area can significantly reduce emission inventory in the automobile sector, which contributes to more than half the VOC emission in Beijing (Liu et al., 2005).

Currently, VOC emissions from gas stations have not been properly included in the emission inventory (Streets et al., 2003). Although our results reveal that VOC emission

Characterization of gas station emissions

J. Zheng et al.

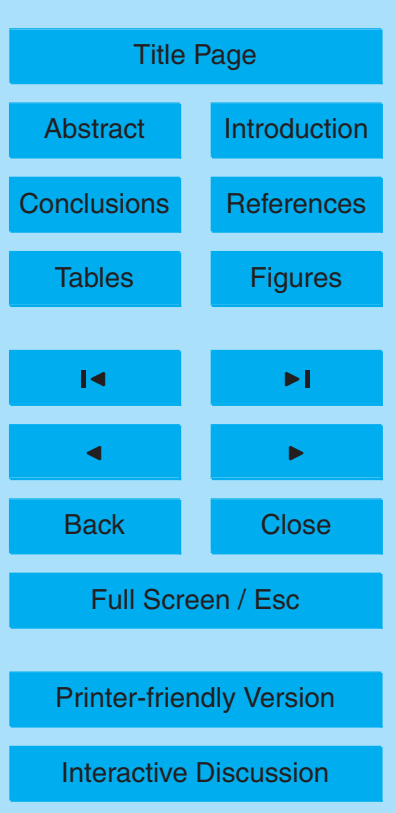

Interactive Discussion 
from gas stations have been significantly reduced in Beijing due to the implementation of more strict regulations and the improvement in vapor recovery technologies, a substantial amount of gasoline is still emitted into the atmosphere. Therefore, an omission of emissions from gas stations may lead to a significant underestimate in VOC emis5 sions in the Beijing megacity and consequently impacts simulations of photochemical ozone production and nucleation and growth of secondary organic aerosol in atmospheric models (Lei et al., 2004; Fan et al., 2006).

\section{Conclusions}

On 6 and 10 August 2008, eight gas stations in Beijing were sampled to characterize 10 VOC emissions. This work represents the first in-situ measurements of gas station VOC emissions using a PTR-MS onboard a mobile laboratory. Aromatics, including benzene, toluene, $\mathrm{C}_{8^{-}}$, and $\mathrm{C}_{9^{-}}$aromatics, methanol, MTBE, butenes, and pentenes were the major VOCs observed by the PTR-MS. The emission rate of each VOC was calculated using a Gaussian point source plume model. On the basis of measurements 15 at the eight gas stations, we estimated that about $4.5 \mathrm{mt} \mathrm{d}^{-1}$ or $1.6 \mathrm{kt} \mathrm{yr}^{-1}$ of gasoline were emitted from the gas stations in Beijing. The corresponding gasoline vapor emission factor was estimated as about $0.5 \mathrm{~kg} \mathrm{t}^{-1}$, showing that gasoline emissions during refueling processes have been decreased substantially since 2002 . In addition, the results showed that, on average, the G2 and G6 gas stations were the most effective 20 in fugitive gasoline vapor recovery while the others emitted about 10 times of gasoline as that of G2 and G6, indicating that further reduction of considerable gasoline vapor emissions can be achieved by improving the gasoline vapor recovery efficiency. The average benzene concentration at G3 was twice as much as the US EPA suggested $\mathrm{RfC}$ level. The type of octane rating enhancers was significantly different among all gas than the others. A noteworthy air pollution control strategy is to enforce methanolblended fuel to reduce $\mathrm{CO}$ and other toxic automobile emissions. Our results indicate

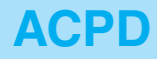

$11,14719-14746,2011$

Characterization of gas station emissions

J. Zheng et al.

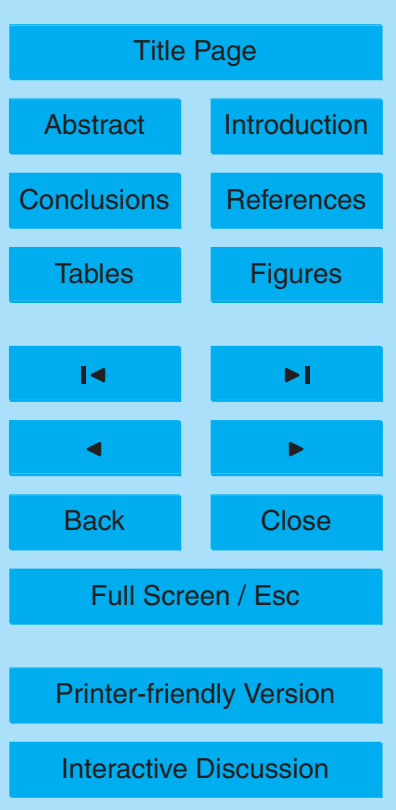


that emissions from gas stations represent an important source for VOCs in megacity Beijing and need to be properly included in emission inventory to assess their roles in photochemical ozone production and secondary organic aerosol formation.

Acknowledgements. This work is part of the Campaign of Atmospheric Research in Beijing and 5 surrounding areas supported by Beijing Environment Protection Bureau (OITC-G08026056) and Beijing Council of Science and Technology (HB200504-6, HB200504-2). This work is also supported by the Robert A. Welch Foundation (Grant A-1417). R. Z. acknowledges further support from the National Natural Science Foundation of China Grant (40728006).

\section{References}

Arnold, S. T., Viggiano, A. A., and Morris, R. A.: Rate constants and product branching fractions for the reactions of $\mathrm{H}_{3} \mathrm{O}^{+}$and $\mathrm{NO}^{+}$with $\mathrm{C}_{2}-\mathrm{C}_{1} 2$ alkanes, J. Phys. Chem. A, 102, 8881-8887, 1998.

Atkinson, R. and Arey, J.: Atmospheric degradation of volatile organic compounds, Chem. Rev., 103, 4605-4638, doi:10.1021/cr0206420, 2003.

15 Chang, C. C., OuYang, C. F., Wang, C. H., Chiang, S. W., and Wang, J. L.: Validation of in-situ measurements of volatile organic compounds through flask sampling and gas chromatography/mass spectrometry analysis, Atmos. Environ., 44, 1301-1307, doi:10.1016/j.atmosenv.2009.12.016, 2010.

de Gouw, J. and Warneke, C.: Measurements of volatile organic compounds in the Earth's atmosphere using proton-transfer-reaction mass spectrometry, Mass Spectrom. Rev., 26, 223-257, 2007.

de Gouw, J. A., Goldan, P. D., Warneke, C., Kuster, W. C., Roberts, J. M., Marchewka, M., Bertman, S. B., Pszenny, A. A. P., and Keene, W. C.: Validation of proton transfer reaction-mass spectrometry (PTR-MS) measurements of gas-phase organic compounds in the atmosphere during the New England Air Quality Study (NEAQS) in 2002, J. Geophys. Res., 108, 4682, doi:10.1029/2003jd003863, 2003.

Fan, J. W., Zhang, R. Y., Collins, D., and Li, G. H.: Contribution of secondary condensable organics to new particle formation: a case study in Houston, Texas, Geophys. Res. Lett., 33, L15802, doi:10.1029/2006gl026295, 2006.
$11,14719-14746,2011$

\section{Characterization of gas station emissions}

J. Zheng et al.

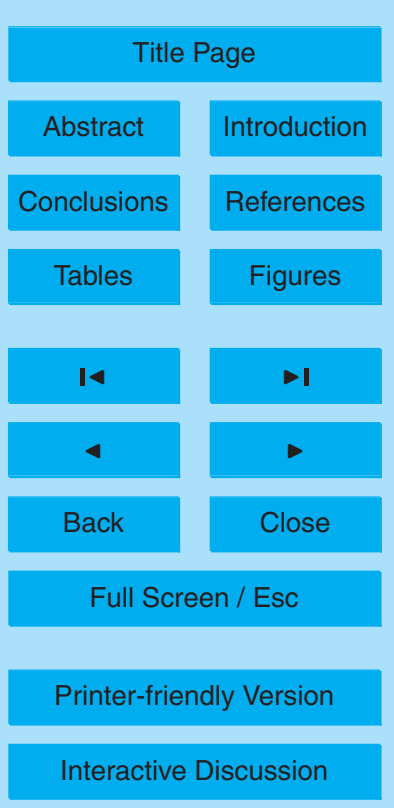

Interactive Discussion 
Finlayson-Pitts, B. J. and Pitts, J. N.: Chemistry of the Upper and Lower Atmosphere: Theory, Experiments and Applications, Academic Press, San Diego, Calif., xxii, 969 pp., 1999.

Fortner, E. C., Zheng, J., Zhang, R., Berk Knighton, W., Volkamer, R. M., Sheehy, P., Molina, L., and André, M.: Measurements of Volatile Organic Compounds Using Proton Transfer Reaction - Mass Spectrometry during the MILAGRO 2006 Campaign, Atmos. Chem. Phys., 9, 467-481, doi:10.5194/acp-9-467-2009, 2009.

Gifford, F. A.: Turbulent diffusion-typing schemes - review, Nucl. Safety, 17, 68-86, 1976.

Han, J. and Hayashi, Y.: Assessment of private car stock and its environmental impacts in China from 2000 to 2020, Transport. Res. D-Tr. E., 13, 471-478, doi:10.1016/j.trd.2008.09.007, $10 \quad 2008$

Hansel, A., Jordan, A., Holzinger, R., Prazeller, P., Vogel, W., and Lindinger, W.: Proton-transfer reaction mass-spectrometry - online trace gas-analysis at the PPB level, Int. J. Mass Spectrom., 149, 609-619, 1995.

Hao, J. M., Hu, J. N., and Fu, L. X.: Controlling vehicular emissions in Beijing during the last 15 decade, Transp. Res. A-Pol., 40, 639-651, doi:10.1016/j.tra.2005.11.005, 2006.

Kuster, W. C., Jobson, B. T., Karl, T., Riemer, D., Apel, E., Goldan, P. D., and Fehsenfeld, F. C.: Intercomparison of volatile organic carbon measurement techniques and data at la porte during the TexAQS2000 Air Quality Study, Environ. Sci. Technol., 38, 221-228, doi:10.1021/es034710r, 2004.

20 Lei, W. F., Zhang, R. Y., Tie, X. X., and Hess, P.: Chemical characterization of ozone formation in the Houston-Galveston area: a chemical transport model study, J. Geophys. Res., 109, D12301, doi:10.1029/2003jd004219, 2004.

Lindinger, W., Hansel, A., and Jordan, A.: On-line monitoring of volatile organic compounds at pptv levels by means of proton-transfer-reaction mass spectrometry (PTR-MS) - medical applications, food control and environmental research, Int. J. Mass Spectrom., 173, 191-241, 1998.

Liu, Y., Shao, M., Zhang, J., Fu, L. L., and Lu, S. H.: Distributions and source apportionment of ambient volatile organic compounds in Beijing city, China, J. Environ. Sci. Health Part A-Toxic/Hazard. Subst. Environ. Eng., 40, 1843-1860, doi:10.1080/10934520500182842, $30 \quad 2005$.

McKeen, S. A. and Liu, S. C.: Hydrocarbon ratios and photochemical history of air masses, Geophys. Res. Lett., 20, 2363-2366, 1993.

National Bureau of Statistics of China: China Energy Statistical Yearbook 2009, edited by:

\section{Characterization of gas station emissions}

J. Zheng et al.

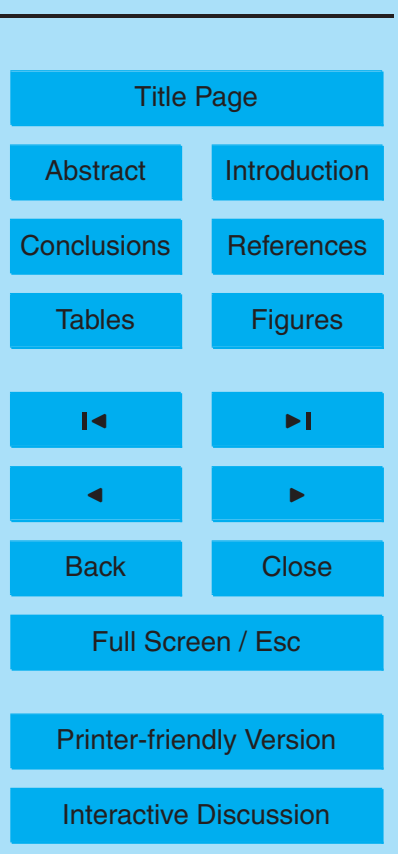

Interactive Discussion 
Geng, Q., China Statistics Press, Beijing, 2010.

Reed, T. B. and Lerner, R. M.: Methanol - versatile fuel for immediate use, Science, 182, 1299-1304, 1973.

Seinfeld, J. H. and Pandis, S. N.: Atmospheric Chemistry and Physics: from Air Pollution to Climate Change, Wiley, New York, xxvii, 1326 pp., 1998.

Shen, M. J., Hao, J. M., and Wang, L. T.: VOC emission situation and control measures of gas station in China, Huan Jing Ke Xue/Chinese J. Environ. Sci., 27, 1473-1478, 2006.

Song, Y., Dai, W., Shao, M., Liu, Y., Lu, S. H., Kuster, W., and Goldan, P.: Comparison of receptor models for source apportionment of volatile organic compounds in Beijing, China,

10 Environ. Pollut., 156, 174-183, doi:10.1016/j.envpol.2007.12.014, 2008.

Streets, D. G., Bond, T. C., Carmichael, G. R., Fernandes, S. D., Fu, Q., He, D., Klimont, Z., Nelson, S. M., Tsai, N. Y., Wang, M. Q., Woo, J. H., and Yarber, K. F.: An inventory of gaseous and primary aerosol emissions in Asia in the year 2000, J. Geophys. Res., 108, 8809, doi:10.1029/2002jd003093, 2003.

Suh, I., Zhang, D., Zhang, R. Y., Molina, L. T., and Molina, M. J.: Theoretical study of $\mathrm{OH}$ addition reaction to toluene, Chem. Phys. Lett., 364, 454-462, doi:10.1016/S00092614(02)01364-7, 2002.

Suh, I., Zhang, R. Y., Molina, L. T., and Molina, M. J.: Oxidation mechanism of aromatic peroxy and bicyclic radicals from $\mathrm{OH}$-toluene reactions, J. Am. Chem. Soc., 125, 12655-12665, doi:10.1021/Ja0350280, 2003.

Tang, $X .:$ The characteristics of urban air pollution in China, in: Urbanization, Energy, and Air Pollution in China, edited by: Fritz, J. J., The National Academies Press, Washington, DC, 47-54, 2004.

Tephly, T. R.: The toxicity of methanol, Life Sci., 48, 1031-1041, 1991.

US EPA: Methyl Tertiary Butyl Ether (MTBE) - Drinking Water, available at: http://www.epa. gov/mtbe/water.htm, last access: May, 2011.

Wang, L., Khalizov, A. F., Zheng, J., Xu, W., Ma, Y., Lal, V., and Zhang, R.: Atmospheric nanoparticles formed from heterogeneous reactions of organics, Nat. Geosci., 3, 238-242, doi:10.1038/ngeo778, 2010.

so Wang, M., Zhu, T., Zheng, J., Zhang, R. Y., Zhang, S. Q., Xie, X. X., Han, Y. Q., and Li, Y.: Use of a mobile laboratory to evaluate changes in on-road air pollutants during the Beijing 2008 Summer Olympics, Atmos. Chem. Phys., 9, 8247-8263, doi:10.5194/acp-9-8247-2009, 2009.

\section{Characterization of gas station emissions}

J. Zheng et al.

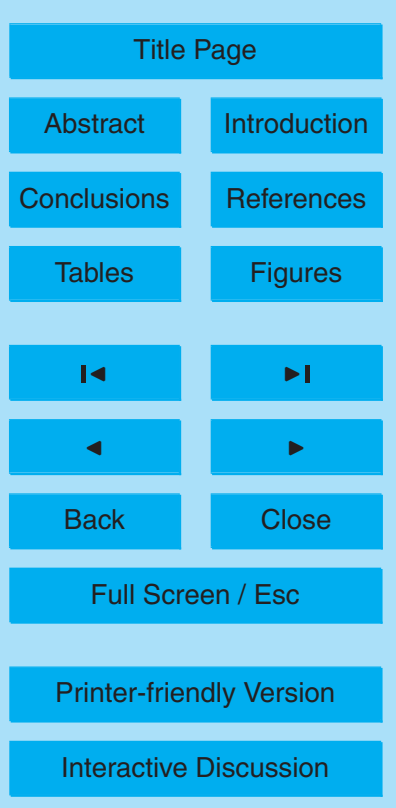

Interactive Discussion 
Yue, D. L., Hu, M., Zhang, R. Y., Wang, Z. B., Zheng, J., Wu, Z. J., Wiedensohler, A., He, L. Y., Huang, X. F., and Zhu, T.: The roles of sulfuric acid in new particle formation and growth in the mega-city of Beijing, Atmos. Chem. Phys., 10, 4953-4960, doi:10.5194/acp-10-49532010, 2010.

5 Zhang, D., Zhang, R. Y., Park, J., and North, S. W.: Hydroxy peroxy nitrites and nitrates from $\mathrm{OH}$ initiated reactions of isoprene, J. Am. Chem. Soc., 124, 9600-9605, doi:10.1021/ja0255195, 2002.

Zhang, R. Y.: Getting to the critical nucleus of aerosol formation, Science, 328, 1366-1367, doi:10.1126/science.1189732, 2010.

10 Zhang, R. Y., Suh, I., Lei, W., Clinkenbeard, A. D., and North, S. W.: Kinetic studies of OHinitiated reactions of isoprene, J. Geophys. Res., 105, 24627-24635, 2000.

Zhang, R. Y., Lei, W. F., Tie, X. X., and Hess, P.: Industrial emissions cause extreme urban ozone diurnal variability, P. Natl. Acad. Sci. USA, 101, 6346-6350, 2004a.

Zhang, R. Y., Suh, I., Zhao, J., Zhang, D., Fortner, E. C., Tie, X. X., Molina, L. T., and

15 Molina, M. J.: Atmospheric new particle formation enhanced by organic acids, Science, 304, 1487-1490, 2004b.

Zhang, R. Y., Li, G. H., Fan, J. W., Wu, D. L., and Molina, M. J.: Intensification of Pacific storm track linked to Asian pollution, P. Natl. Acad. Sci. USA, 104, 5295-5299, doi:10.1073/pnas.0700618104, 2007.

20 Zhao, J. and Zhang, R. Y.: Proton transfer reaction rate constants between hydronium ion $\left(\mathrm{H}_{3} \mathrm{O}^{+}\right)$and volatile organic compounds, Atmos. Environ., 38, 2177-2185, doi:10.1016/j.atmosenv.2004.01.019, 2004.

Zhao, J., Zhang, R. Y., Misawa, K., and Shibuya, K.: Experimental product study of the $\mathrm{OH}$-initiated oxidation of $m$-xylene, J. Photoch. Photobio. A, 176, 199-207, doi:10.1016/j.jphotochem.2005.07.013, 2005.

Zhao, J., Levitt, N. P., Zhang, R. Y., and Chen, J. M.: Heterogeneous reactions of methylglyoxal in acidic media: implications for secondary organic aerosol formation, Environ. Sci. Technol., 40, 7682-7687, doi:10.1021/es060610k, 2006.

Zhao, J., Khalizov, A., Zhang, R. Y., and McGraw, R.: Hydrogen-bonding interaction in molec30 ular complexes and clusters of aerosol nucleation precursors, J. Phys. Chem. A, 113, 680689, doi:10.1021/jp806693r, 2009.

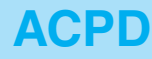

11, 14719-14746, 2011

Characterization of gas station emissions

J. Zheng et al.

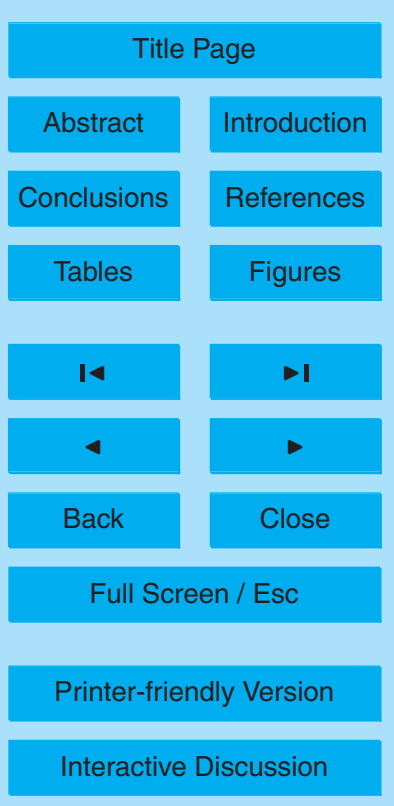


Table 1. Summary of the gas station measurement trip on 6 August 2008.

\begin{tabular}{lccccc}
\hline Gas station & $\begin{array}{c}\text { Gas station } \\
\text { location }\end{array}$ & $\begin{array}{c}\text { Number of } \\
\text { gasoline } \\
\text { plumes }\end{array}$ & $\begin{array}{c}\text { Duration } \\
\text { measurement }\end{array}$ & $\begin{array}{c}\text { Wind } \\
\text { direction } \\
\text { and speed }\end{array}$ & $\begin{array}{c}\mathrm{T}\left({ }^{\circ} \mathrm{C}\right) \\
\text { and } \\
\mathrm{RH}(\%)\end{array}$ \\
\hline $\mathrm{G} 1$ & $116^{\circ} 18^{\prime} 34.6^{\prime \prime} \mathrm{E}$ & 4 & $08: 14-08: 29$ & $\mathrm{~N}$ & 27.3 \\
& $39^{\circ} 59^{\prime} 56.94^{\prime \prime} \mathrm{N}$ & & & $0.58 \mathrm{~m} \mathrm{~s}^{-1}$ & 72.6 \\
$\mathrm{G} 2$ & $116^{\circ} 18^{\prime} 29.74^{\prime \prime} \mathrm{E}$ & 5 & $08: 41-09: 01$ & $\mathrm{~N}$ & 27.7 \\
& $40^{\circ} 01^{\prime} 14.74^{\prime \prime} \mathrm{N}$ & & & $0.56 \mathrm{~m} \mathrm{~s}^{-1}$ & 70.6 \\
$\mathrm{G} 3$ & $116^{\circ} 16^{\prime} 33.71^{\prime \prime} \mathrm{E}$ & 3 & $09: 16-09: 31$ & $\mathrm{~N}$ & 27.3 \\
& $40^{\circ} 01^{\prime} 15.92^{\prime \prime} \mathrm{N}$ & & & $0.34 \mathrm{~m} \mathrm{~s}^{-1}$ & 70.1 \\
\hline
\end{tabular}

$11,14719-14746,2011$

Characterization of gas station emissions

J. Zheng et al.

Title Page

Abstract Introduction

Conclusions

References

Tables

Figures

14

4

Back

Full Screen / Esc

Printer-friendly Version

Interactive Discussion 
Table 2. Summary of the gas station measurement trip on 10 August 2008.

\begin{tabular}{lccccc}
\hline Gas station & $\begin{array}{c}\text { Gas station } \\
\text { location }\end{array}$ & $\begin{array}{c}\text { Number of } \\
\text { gasoline } \\
\text { plumes }\end{array}$ & $\begin{array}{c}\text { Duration } \\
\text { measurement }\end{array}$ & $\begin{array}{c}\text { Wind } \\
\text { direction } \\
\text { and speed }\end{array}$ & $\begin{array}{c}\mathrm{T}\left({ }^{\circ} \mathrm{C}\right) \\
\text { and } \\
\mathrm{RH}(\%)\end{array}$ \\
\hline $\mathrm{G} 4$ & $\begin{array}{c}116^{\circ} 17^{\prime} 51.9^{\prime \prime} \mathrm{E} \\
40^{\circ} 02^{\prime} 1.58^{\prime \prime} \mathrm{N}\end{array}$ & 5 & $09: 58-10: 13$ & $\mathrm{~N}$ & 26.8 \\
& $116^{\circ} 19^{\prime} 42.6^{\prime \prime} \mathrm{E}$ & 5 & $10: 28-10: 34$ & $\mathrm{~N}$ & 26.9 \\
$\mathrm{G} 5$ & $40^{\circ} 02^{\prime} 08^{\prime \prime} \mathrm{N}$ & & & $0.50 \mathrm{~m} \mathrm{~s}^{-1}$ & 80.8 \\
& $116^{\circ} 19^{\prime} 45.6^{\prime \prime} \mathrm{E}$ & 3 & $11: 10-11: 26$ & $\mathrm{~N}$ & 26.1 \\
$\mathrm{G} 6$ & $39^{\circ} 58^{\prime} 32.4^{\prime \prime} \mathrm{N}$ & & & $0.31 \mathrm{~m} \mathrm{~s}^{-1}$ & 84.1 \\
& $116^{\circ} 19^{\prime} 30.6^{\prime \prime} \mathrm{E}$ & 5 & $11: 32-11: 46$ & $\mathrm{~N}$ & 26.7 \\
$\mathrm{G} 7$ & $39^{\circ} 57^{\prime} 57^{\prime \prime} \mathrm{N}$ & & & $0.24 \mathrm{~m} \mathrm{~s}^{-1}$ & 82.1 \\
& $116^{\circ} 18^{\prime} 38.4^{\prime \prime} \mathrm{E}$ & 3 & $11: 55-12: 09$ & $\mathrm{~N}$ & 27.0 \\
$\mathrm{G} 8$ & $39^{\circ} 58^{\prime} 52.2^{\prime \prime} \mathrm{N}$ & & & $0.32 \mathrm{~m} \mathrm{~s}^{-1}$ & 83.1 \\
\hline
\end{tabular}

\section{ACPD}

$11,14719-14746,2011$

Characterization of gas station emissions

\section{J. Zheng et al.}

Title Page

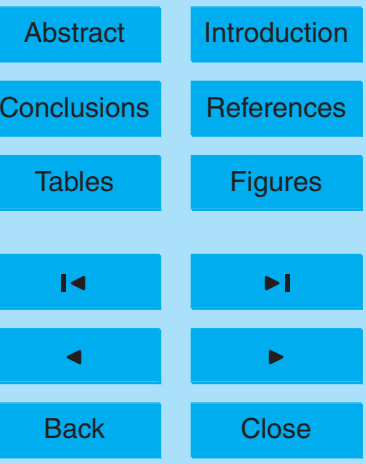

Full Screen / Esc

Printer-friendly Version

Interactive Discussion 


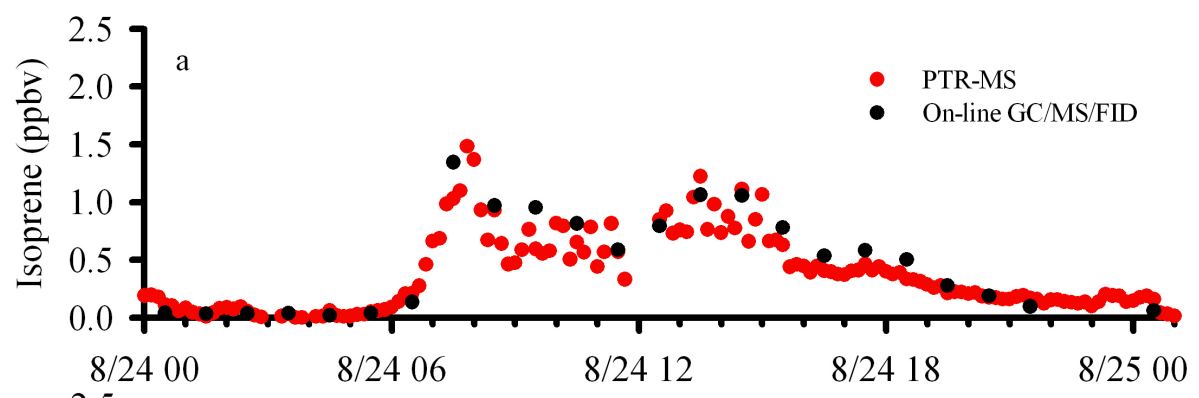

\section{ACPD}

$11,14719-14746,2011$

Characterization of gas station emissions

\section{J. Zheng et al.}
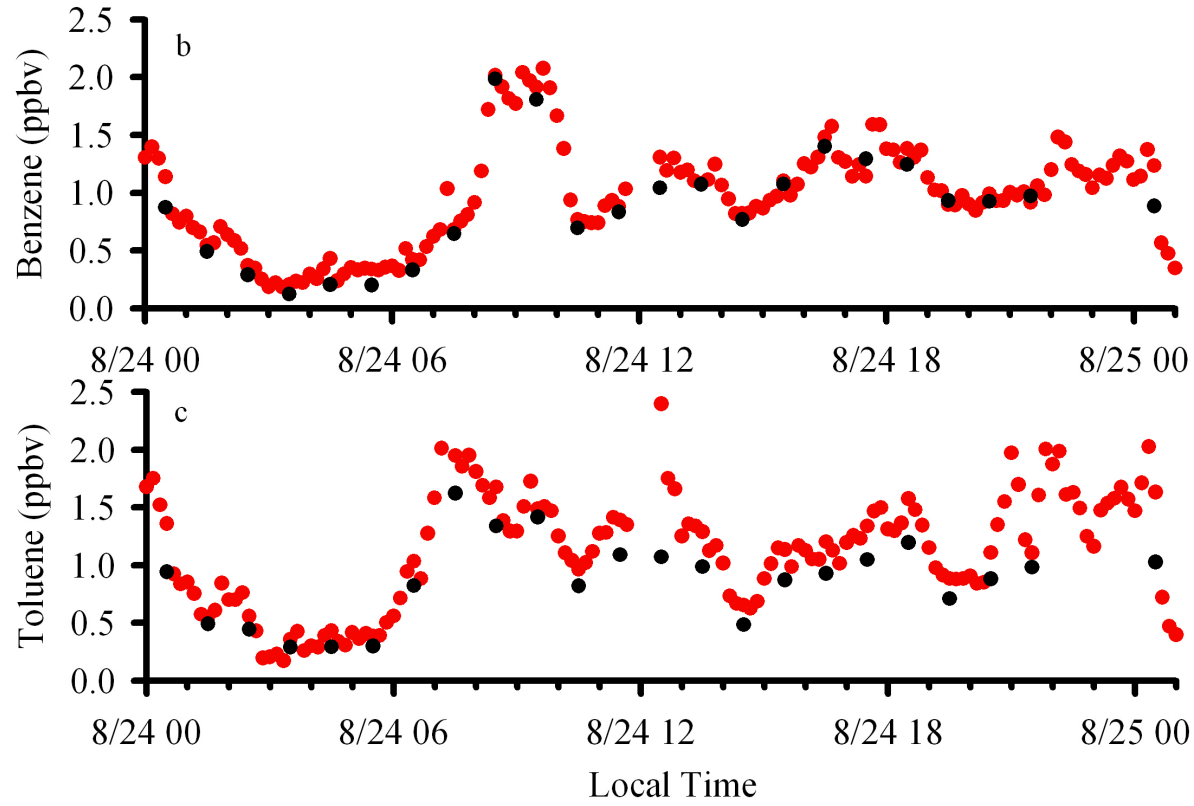

Fig. 1. Inter-comparison between the PTR-MS and the GC/MS/FID system in (a) isoprene, (b) benzene, and (c) toluene measurements on 24 August at the Peking University ground site.

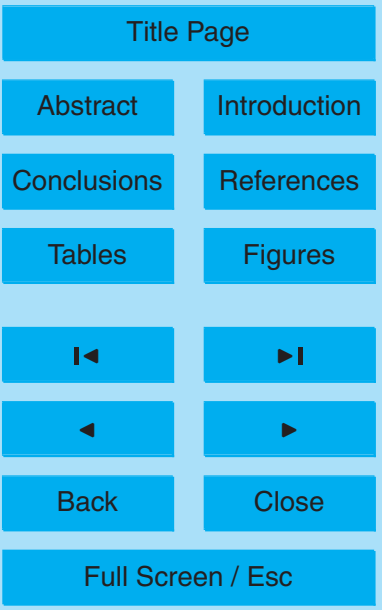

Printer-friendly Version

Interactive Discussion

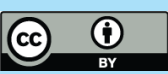




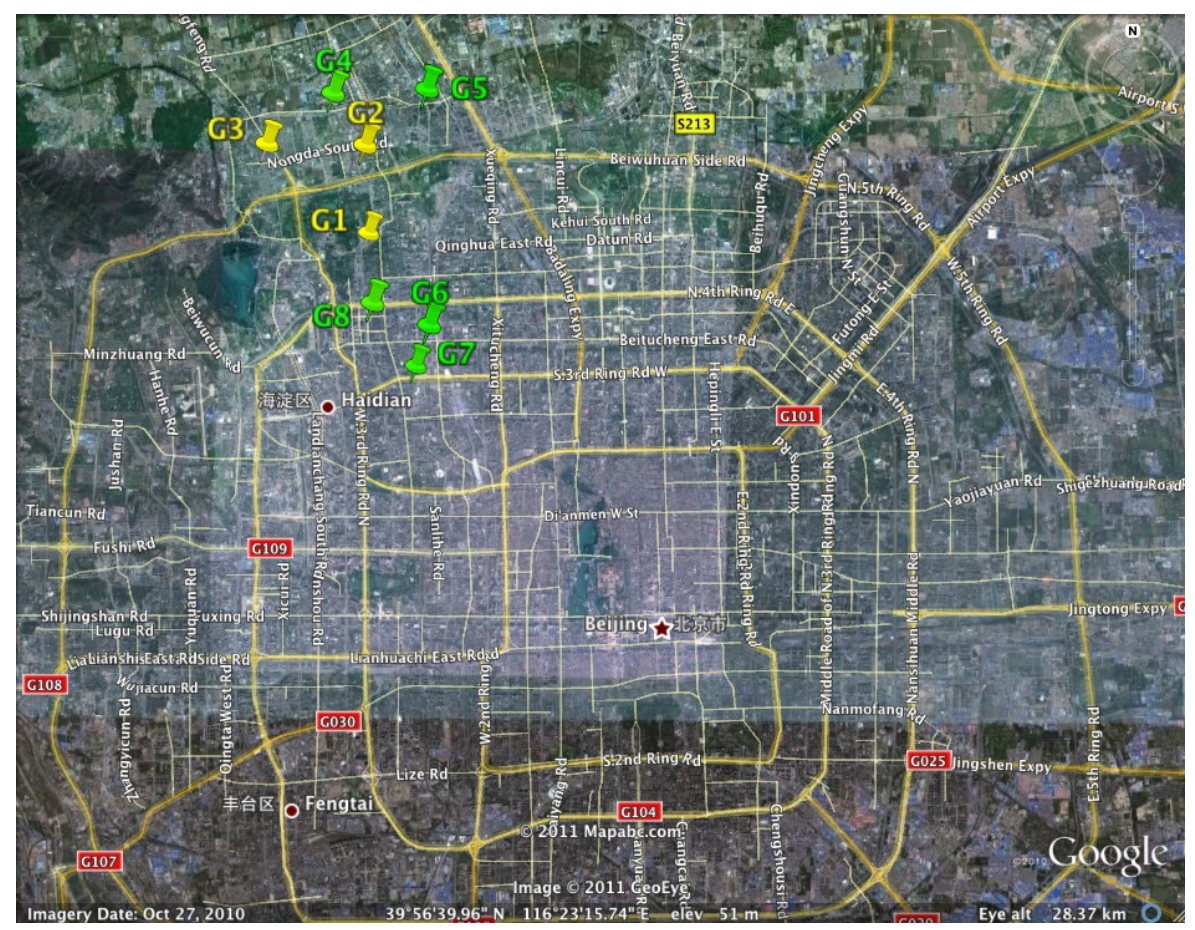

Fig. 2. Locations of the eight gas stations visited by the ML on 6 (yellow marker) and 10 August (green marker).
ACPD

$11,14719-14746,2011$

Characterization of gas station emissions

J. Zheng et al.

Title Page

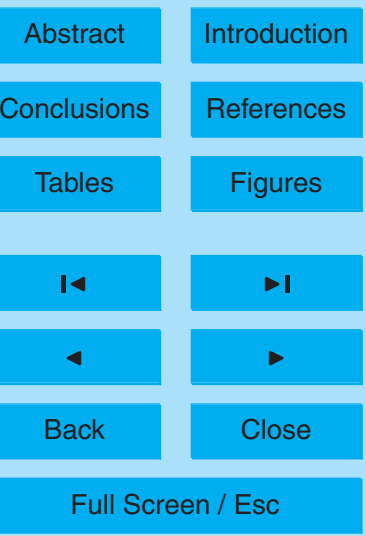

Printer-friendly Version

Interactive Discussion 


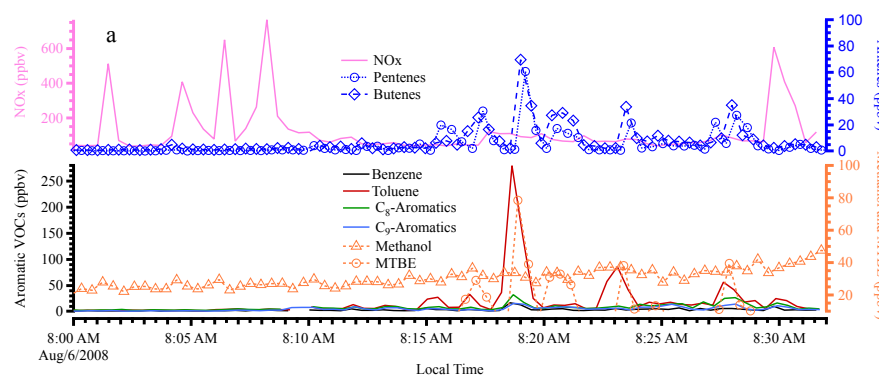

\section{ACPD}

$11,14719-14746,2011$

Characterization of gas station emissions

J. Zheng et al.

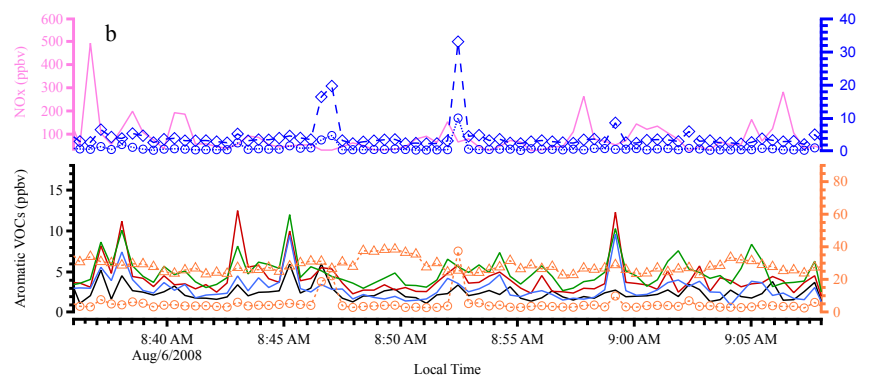

Title Page

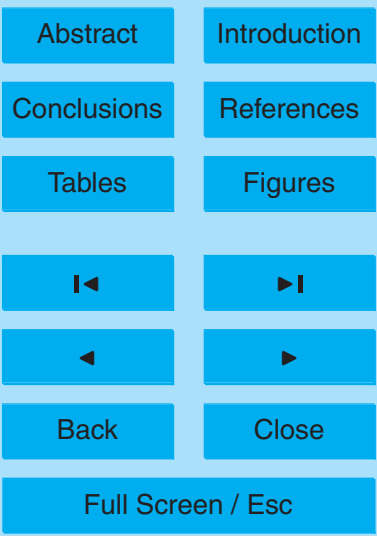

Printer-friendly Version

Fig. 3. Aromatics, methanol, MTBE, butenes, pentenes and $\mathrm{NO}_{x}$ observed at (a) $\mathrm{G} 1$, (b) G2 and (c) G3. Transient high levels of $\mathrm{NO}_{\mathrm{x}}$ are due to fresh on-road emissions.

Interactive Discussion 


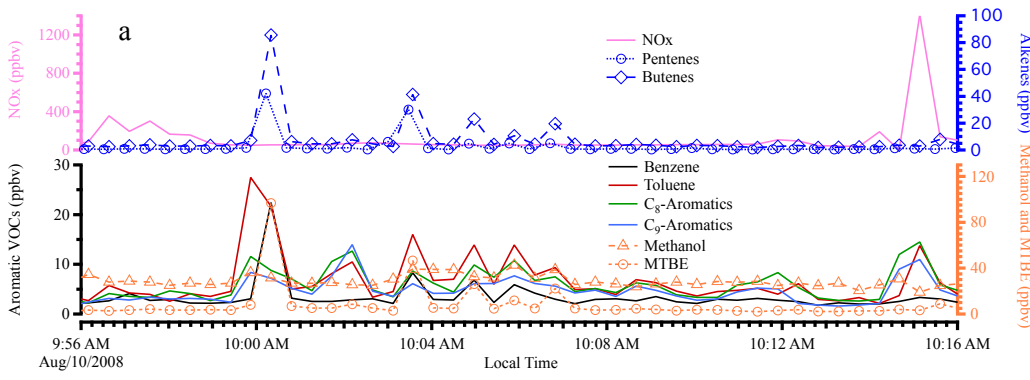

\section{ACPD}

11, 14719-14746, 2011

Characterization of gas station emissions

J. Zheng et al.

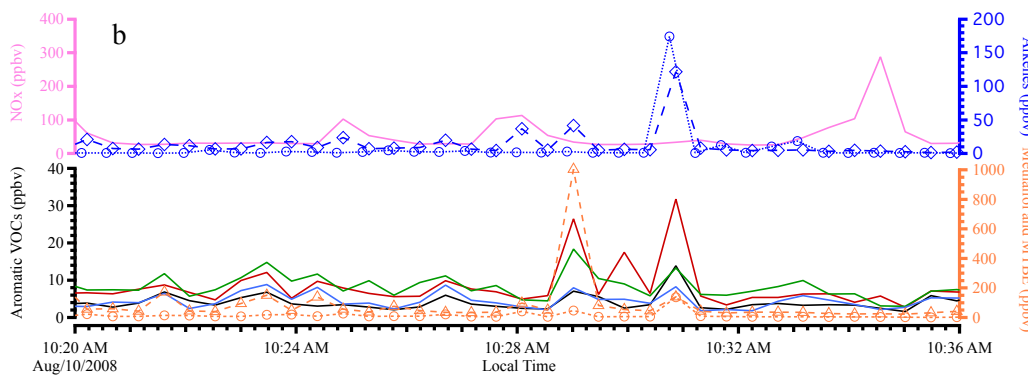

Title Page
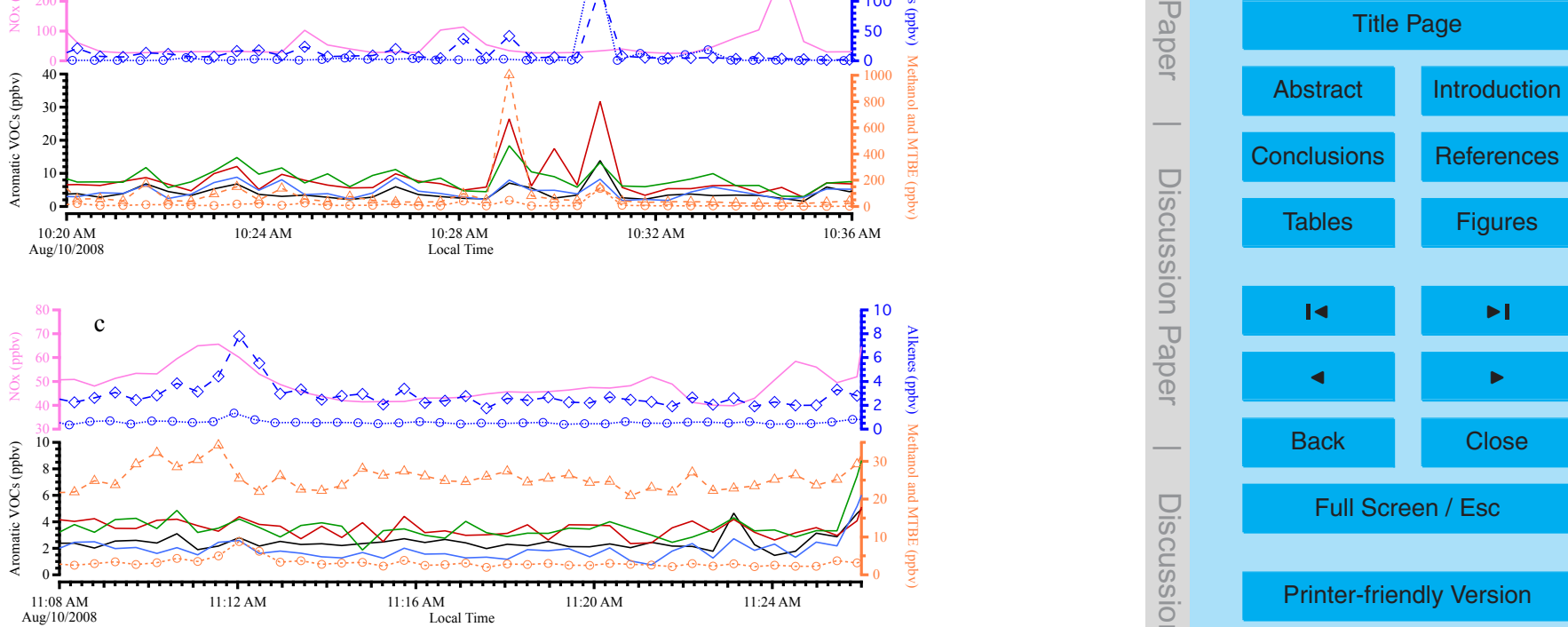

Printer-friendly Version

Fig. 4. Aromatics, methanol, MTBE, butenes, pentenes and $\mathrm{NO}_{x}$ observed at (a) G4, (b) G5, (c) G6, (d) G7, and (e) G8. Transient high levels of $\mathrm{NO}_{x}$ are due to fresh on-road emissions.

Interactive Discussion

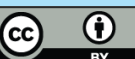




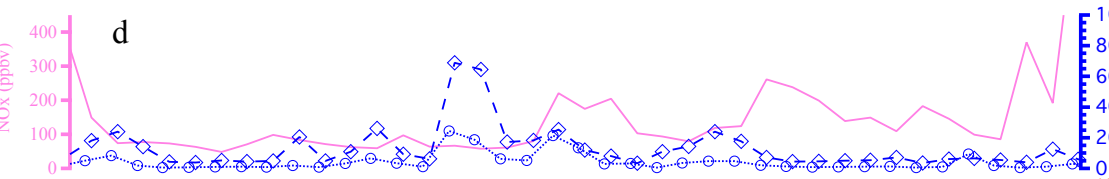

\section{ACPD}

11, 14719-14746, 2011

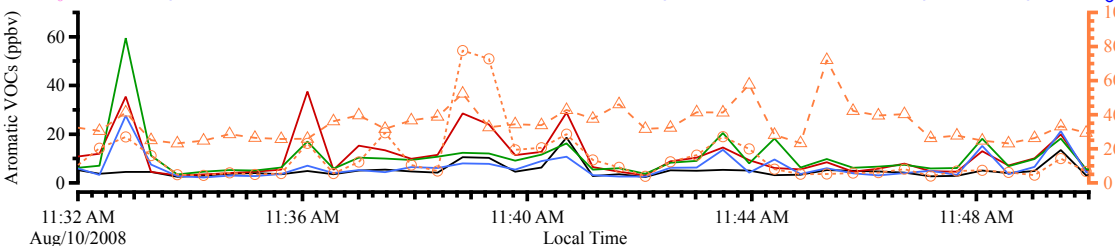

Characterization of gas station emissions

J. Zheng et al.

Title Page

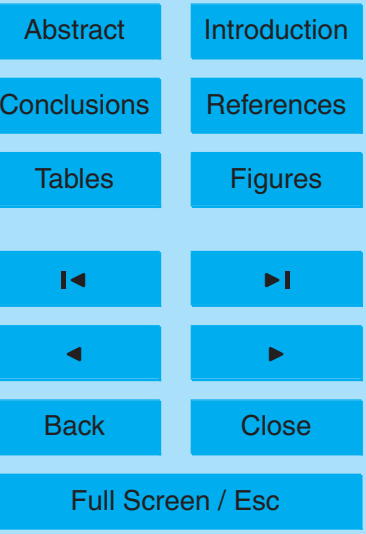

Fig. 4. Continued.

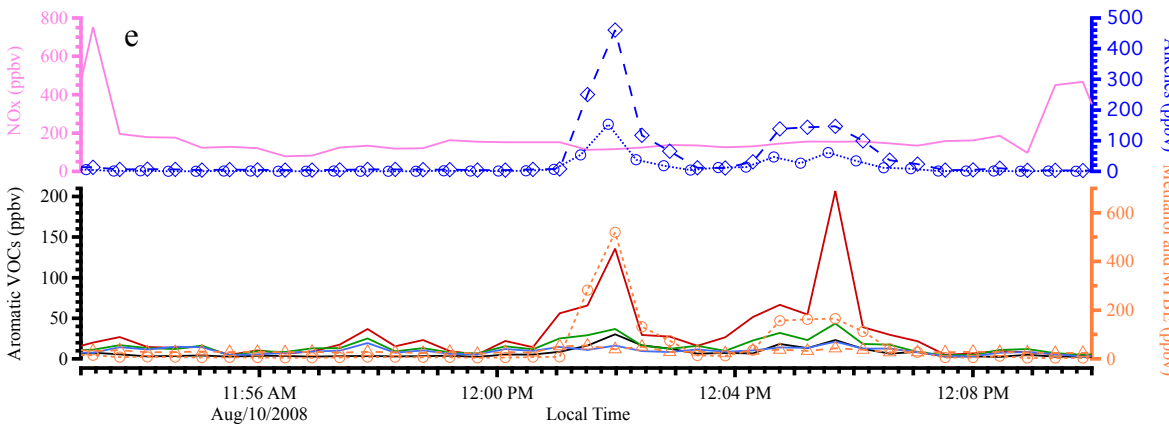

Interactive Discussion 


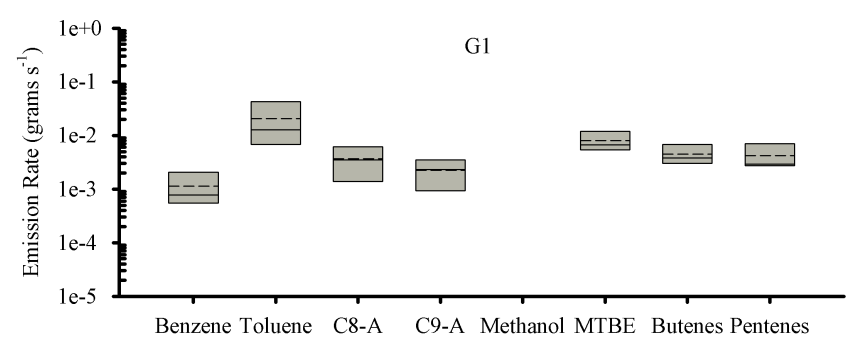

\section{ACPD}

$11,14719-14746,2011$

\section{Characterization of} gas station emissions

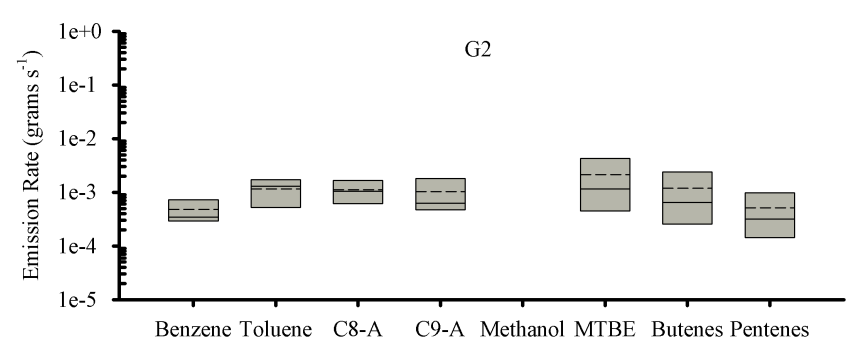

\section{J. Zheng et al.}

Title Page

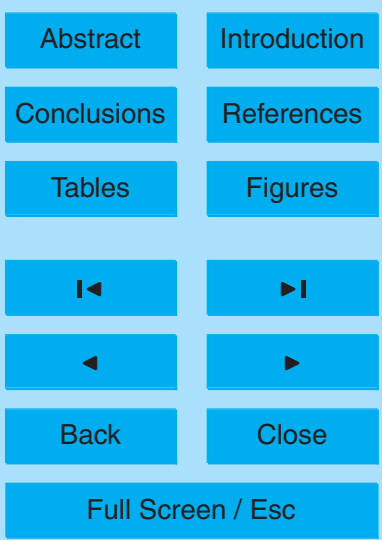

Printer-friendly Version

Fig. 5. Box plots of calculated emission rates $\left(\mathrm{g} \mathrm{s}^{-1}\right)$ of benzene, toluene, $C_{8}$-aromatics $\left(C_{8}-A\right)$, $\mathrm{C}_{9}$-aromatics $\left(\mathrm{C}_{9}-\mathrm{A}\right)$, methanol, MTBE, butenes and pentenes at all eight gas stations. Each box shows the minimum and maximum emission rates of the species and the dash and solid lines indicate the mean and median values, respectively.

Interactive Discussion 


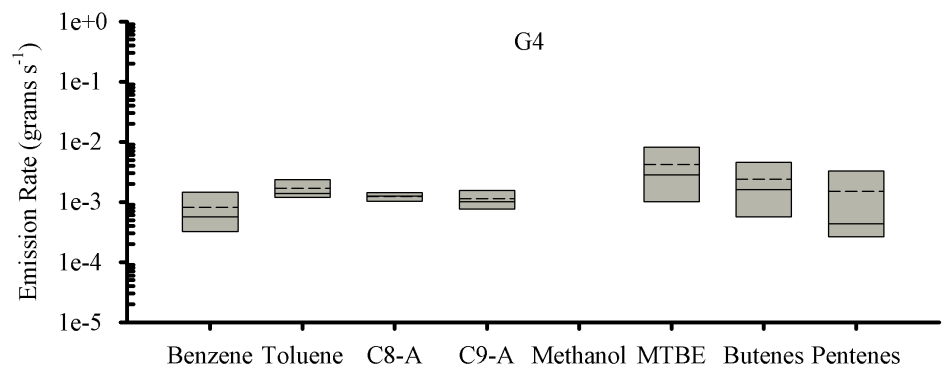

\section{ACPD}

11, 14719-14746, 2011

\section{Characterization of gas station emissions}

\section{J. Zheng et al.}

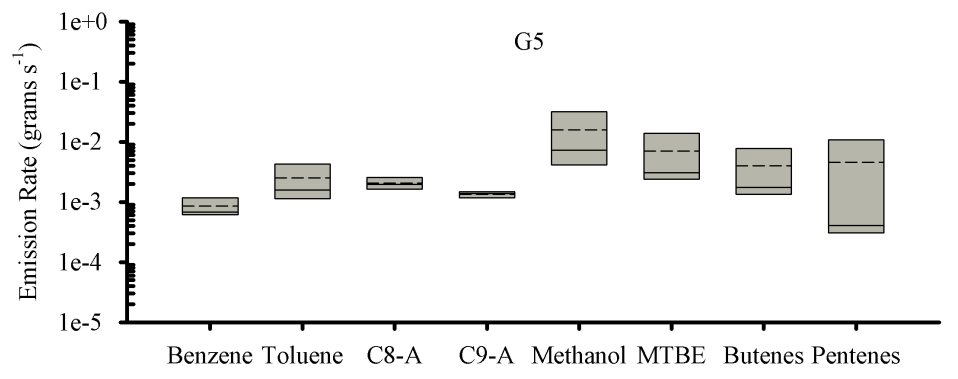

Title Page

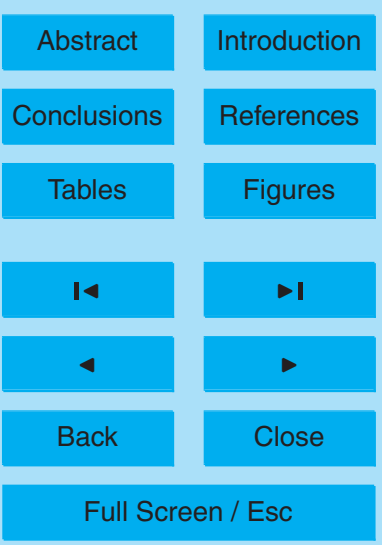

Printer-friendly Version

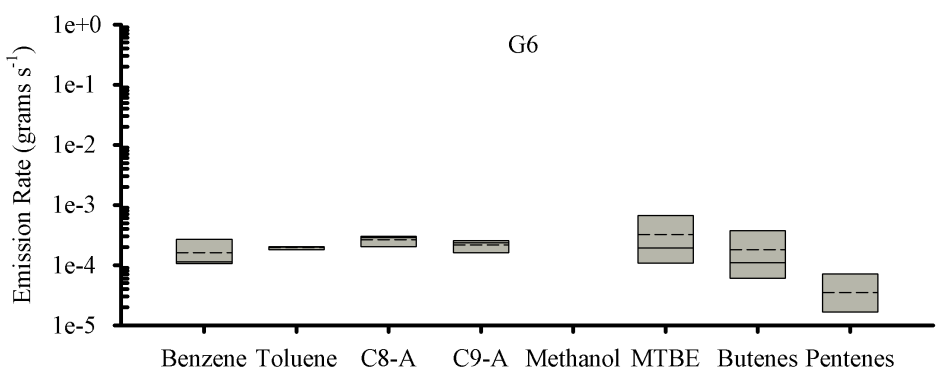

Interactive Discussion

Fig. 5. Continued. 


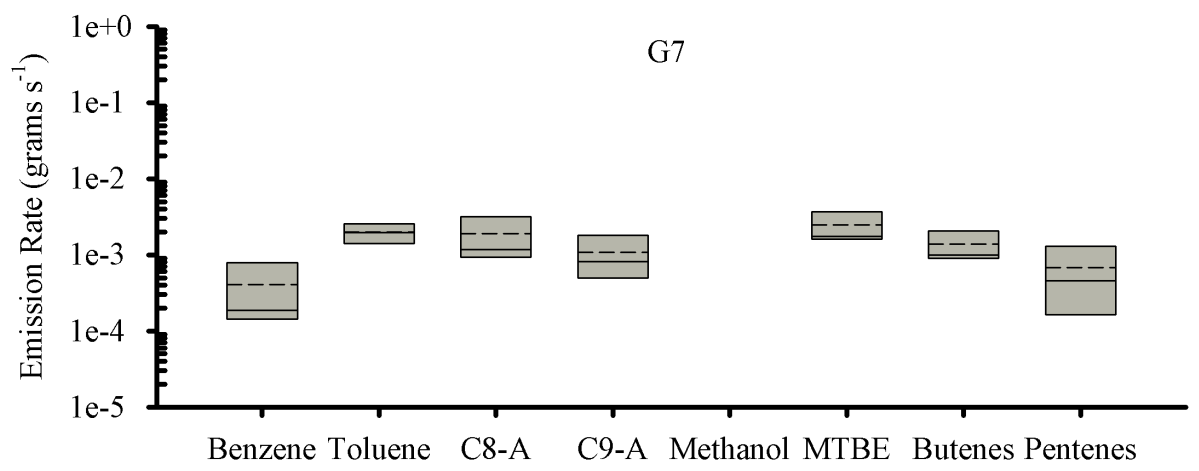

\section{ACPD}

11, 14719-14746, 2011

\section{Characterization of} gas station emissions

\section{J. Zheng et al.}

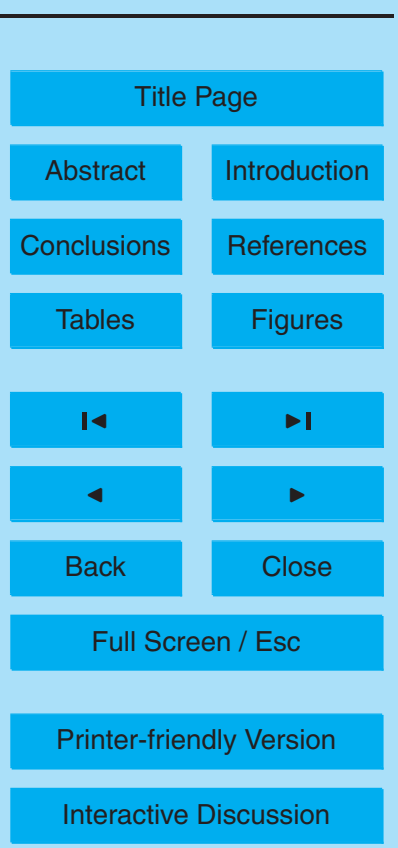




\section{ACPD}

11, 14719-14746, 2011

Characterization of gas station

emissions

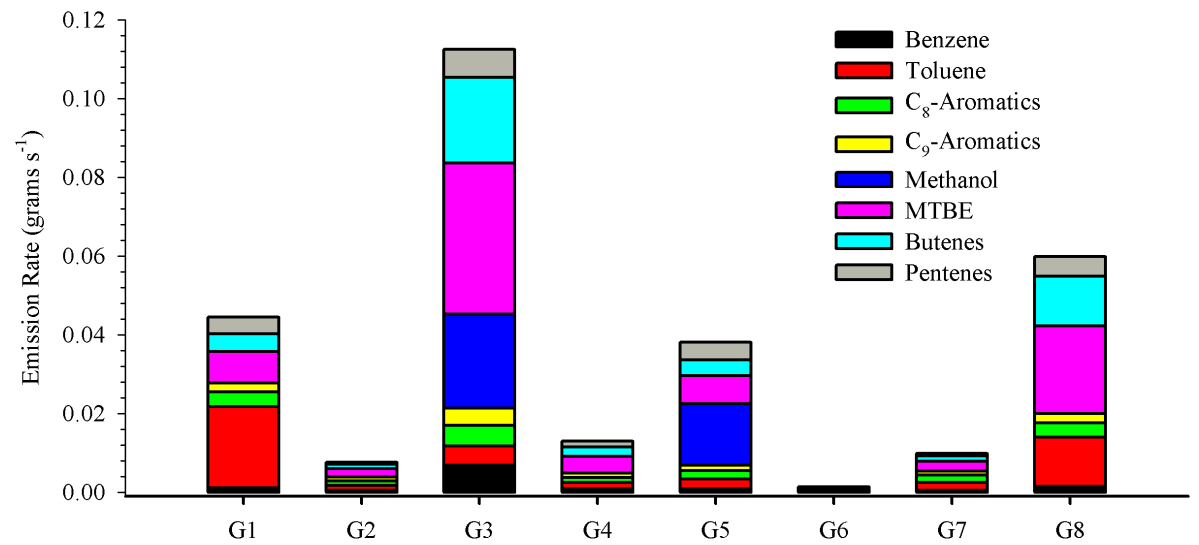

J. Zheng et al.

Title Page

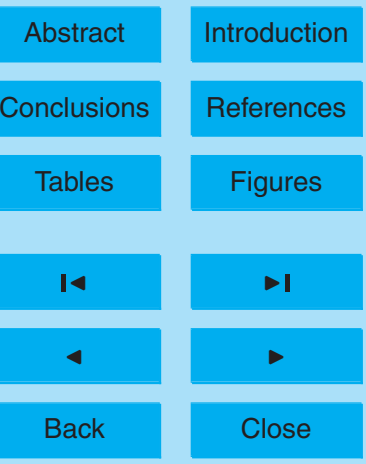

Full Screen / Esc

Printer-friendly Version

Interactive Discussion 